\title{
Postharvest treatment of pyroligneous acid on solanaceous crops at different storage condition
}

\section{MAM Sudaria, EM Lungsod, AC Robles, CL Gepte \& RM Yabao}

Journal of Agriculture and Ecology

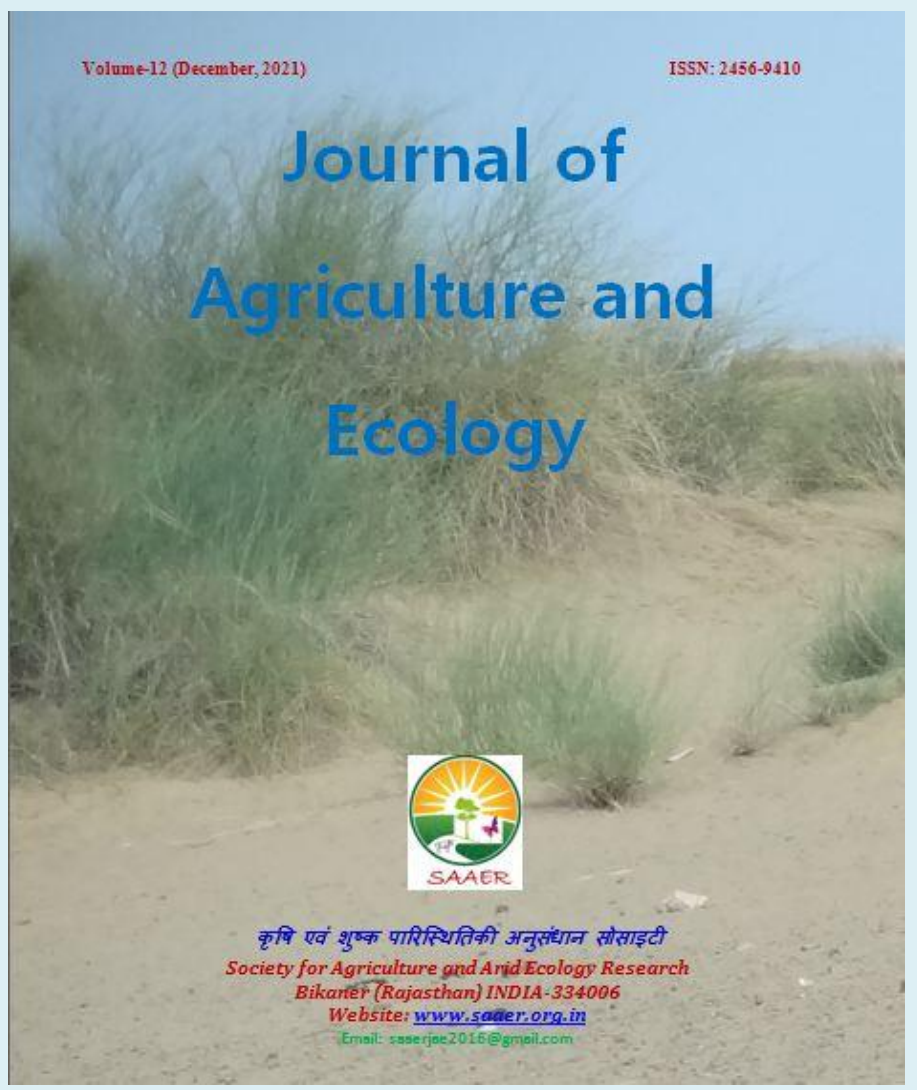

ISSN: 2456-9410

Volume: 12

Journal of Agriculture and Ecology (2021) 12: 44-56 http://doi.org/10.53911/JAE.2021.12203 


\title{
Postharvest treatment of pyroligneous acid on solanaceous crops at different storage condition
}

\author{
MAM Sudaria $\not$, EM Lungsod, AC Robles, CL Gepte, and RM Yabao \\ College of Agriculture and Technology, Northwest Samar State University, Calbayog City, Samar, \\ Philippines 6710 \\ Corresponding author: MAM Sudaria, Email: michael.sudaria@nwssu.edu.ph
}

\begin{tabular}{l} 
Article Info \\
\hline Article history \\
Received: 02 November 2021 \\
Accepted: 20 December 2021 \\
Available online: 30 December \\
2021
\end{tabular}

Key Words: Capsicums, pyrolysis, shelf life, solanaceous, wood vinegar.

\begin{abstract}
Pyroligneous acid or wood vinegar is a liquid produced through natural carbonization of plant refuse and has been reported to improve harvest quality of vegetables. This study makes use of pyroligneous acid derived from bamboo refuse and applied as postharvest treatment on fruits of two solanaceous crops namely hot pepper and eggplant prior to storage. A $2 \times 3$ factorial experiment was laid out in two (2) sets of experiments in Completely Randomized Design with six treatment combinations and thirty replicates. Hot pepper (var. Chain Fair) and Eggplant (var. Fortuner) fruit samples were dipped for $1 \mathrm{~min}$ at different concentration of pyroligneous acid with control (no application), $20 \% \mathrm{v} / \mathrm{v}$ and $30 \% \mathrm{v} / \mathrm{v}$ and were stored at ambient $\left(25-30^{\circ} \mathrm{C}\right)$ and refrigerated $\left(8-10^{\circ} \mathrm{C}\right)$ conditions for a week. Fruits of both crops reached its limit of marketability at visual quality rating index of three in the $4^{\text {th }}$ day of storage. Morphological characteristics particularly visual quality, firmness, shelf life and degree of shriveling was maintained better when stored under refrigerated condition. Fruit decay incidence regardless of storage condition was reduced especially with higher concentration of pyroligneous acid treatment. However, there were no marked variations of pyroligneous treatment on physico-chemical characteristics, color change, water content and dry matter content of hot pepper. The application of pyroligneous acid at 30\% v/v retained better total soluble solid content of eggplant irrespective with storage conditions. Nonetheless, refrigeration delayed color changes, $\%$ cumulative weightloss, $\mathrm{pH}$, fruit size, degree of shriveling and firmness.
\end{abstract}

Copyright (C2021 Sudaria et al., This is an open access article published under the terms of the Creative Commons Attribution License, which permits unrestricted use, distribution, and reproduction in any medium, provided the original work is properly cited.

Preferred citation: Sudaria MAM, Lungsod EM, Robles AC, Gepte CL \& Yabao RM. 2021. Postharvest treatment of pyroligneous acid on solanaceous crops at different storage condition. Journal of Agriculture and Ecology, 12: 44-56; http://doi.org/10.53911/JAE.2021.12203.

\section{Introduction}

Solanaceous crops are good sources of vitamins, fibers, minerals and antioxidants and are commercially important crop in the Philippines. Most varieties of hot pepper (Capsicum annuum L.) produce capsaicinoids, which are responsible for their characteristic hot pungent taste. Hot pepper is also rich in phenolic-derived compounds with strong physiological and pharmacological properties (Seo-Young Oh and Seok Chan Koh 2019). Eggplant (Solanum melongena L.) also known as brinjal, and aubergine is one of the most important, inexpensive and popular vegetable 
crops grown and consumed in Asia. In the Philippines, eggplant production accounts for more than $30 \%$ of the total volume of production of the most important vegetables in the country and provides an important source of cash income, particularly for small, resource-poor farmers (Hautea et al. 2016). Often cited under postproduction problem is the lack of information to manage the high perishability of harvested vegetables (Salas et al. 2015). It has been reported that $40-50 \%$ of horticultural crops produced in developing countries are lost before they can be consumed, mainly because of high rates of bruising, water loss, and subsequent decay during postharvest handling. Nutritional loss (loss of vitamins, antioxidant, and healthpromoting substances) or decreased market value is another important loss that occurs in fresh produce. Quality of fresh produce is governed by many factors. The combined effect of all decides the rate of deterioration and spoilage and if these factors are not controlled properly, will lead to postharvest losses on large scale (Ahmad and Siddiqui 2016).

Revival of pyroligneous acid (wood vinegar) application in agriculture and human health was prompted by the drive to develop organic and environment-friendly production systems and natural medicines. The strong antimicrobial activity of pyroligneous acid was correlated to its high contents of organic acids and phenolic substances. Pyroligneous acid also exhibits antioxidant activity and was found to have superior free radical scavenging activity (Loo et al. 2007). The strong antioxidant activity is due to its high content of phenols. Wood vinegar consists of more than 200 water soluble compounds comprising of organic acids, phenolic, alkane, alcohol and ester compounds (Wei et al. 2010). Wood vinegar has many uses, in agriculture it is used in pest and disease control, improving yield and quality, increasing fruit size, weight and sweetness, and extending shelf life of fruit and vegetables (Mohan et al. 2006; Oramahi \& Yoshimura 2013; Tuntika et al. 2013; Zulkarami et al. 2011).

With the increasing demand for fresh fruit and vegetables, postharvest technology for extending shelf-life of these perishable commodities has gained significant importance in recent years. The principal physiological factors that negatively impact fruit quality during shipment and storage and subsequent marketing are water loss and chilling injury. The skin of fruit and vegetables plays an important role in gas exchange between the product and the surrounding environment, and for this reason the protection of the pericarp against dehydration is particularly important after harvest, when fruits do not receive water or nutrients from the plant. Therefore, implementation of techniques to preserve the physicochemical properties of the pericarp could help to preserve fruit quality during the storage period (Crespo \& del Amor 2010). Consumers usually judge the quality of fresh fruits based on appearance and freshness at the time of purchase. There are many successful postharvest techniques (such as controlled atmosphere, modified atmosphere packaging, plastic film packaging, etc.) which have become standard practice, however edible coatings and many other postharvest treatments are of great interest and continue to 
be extensively studied for their potential ability to maintain the quality of fresh fruits and vegetables (Youssef et al. 2015). Pyroligneous acid has been reported to have numerous potential benefits both to agriculture and human health and to enhance harvest and postharvest quality of various fruits and vegetables (Valida et al. 2016). Hence, this study investigated the use of varying concentration of pyroligneous acid as postharvest treatment on the quality and shelflife of two solanaceous crops stored in different storage conditions.

\section{Materials and Methods}

\section{Sample preparation}

Freshly harvested, uniformly sized and defect-free hot pepper cv. Chain Fair and eggplant cv. Fortuner were brought to the agriculture laboratory room of the College of Agriculture and Technology, Northwest Samar State University, Calbayog City, Samar for evaluation. Hot pepper and eggplant were sorted out again for uniform sizes, free from defects, bruises, deformities, and any debris before experimental lay-out, pyroligneous acid treatment and storage. Hot pepper and eggplant fruit samples were treated with pyroligneous acid derived from slow pyrolysis of bamboo tree refuse and corn stover at dilutions of $200 \mathrm{ml}$ pyroligneous acid:1,000 $\mathrm{ml}$ water $(20 \% \mathrm{v} / \mathrm{v})$ and $300 \mathrm{ml}$ pyroligneous acid: $1,000 \mathrm{ml}$ water $(30 \% \mathrm{v} / \mathrm{v})$ at $1 \mathrm{~min}$ dipping time prior to storage at ambient (25$\left.30^{\circ} \mathrm{C}\right)$ and refrigerated $\left(8-10^{\circ} \mathrm{C}\right)$ conditions for a week. Fruits dipped in distilled water for 1 min served as the control. The pyroligneous acid used was prepared by the Abuyog Experimental Station, Abuyog Leyte,
Philippines. The chemical composition per liter of pyroligneous acid is shown in Table 1.

Table 1. Chemical component of pyroligneous acid (wood vinegar) used from bamboo refuse

\begin{tabular}{|c|c|c|}
\hline $\begin{array}{c}\text { Name of } \\
\text { Chemicals }\end{array}$ & Mg/1000cc & pH \\
\hline Methanol & 2662 & $2-3$ \\
\hline Ethanol & 26 & \\
\hline Acetone & 154 & \\
\hline Acetic acid & 15,224 & \\
\hline Propionic aid & 649 & \\
\hline Lactic acid & 240 & \\
\hline Phenol & 354 & \\
\hline Benzonic acid & 28 & \\
\hline Furfural & 2151 & \\
\hline Guaiacol & 260 & \\
\hline Syringol & 209 & \\
\hline Cyclotene & 113 & \\
\hline
\end{tabular}

Source: Abuyog Experimental Station, Abuyog Leyte, Philippines

\section{Experimental Design and Lay-out}

A $2 \times 3$ factorial experiment was laid out in two sets of experiments in Completely Randomized Design (CRD) with thirty (30) replicate fruit samples per treatment combination each for hot pepper and eggplant. Sample fruits were monitored daily to determine the response of green matured hot pepper and eggplant to the varying levels of pyroligneous acid concentration and different storage conditions. Peel color reddening was measured daily using the colorimeter app by recording the $\left(\mathrm{L}^{*}, \mathrm{a}^{*}, \mathrm{~b}^{*}\right.$ values $)$ until it reaches a visual quality rating $(\mathrm{VQR})$ of 5 that limits the marketability. L* - lightness (0$100), a^{*}-(+$ red $)(-$ green $), b^{*}-(+$ yellow $)(-$ 
blue). Weight loss as percent of the initial weight was measured using the digital weighing scale (SF-400) with a capacity of $7,000 \mathrm{~g}$ x $1 \mathrm{~g} / 248 \mathrm{oz}$. Cumulative weightloss, decay incidence $(\%)$ and visual quality rating (VQR) was evaluated using the rating indices (Benitez et.al, 2021). Fruit firmness was measured using the rating scale of 1-firm to hard, 2-first perceptible softening, 3moderately soft and 4-ripe soft. Shriveling index using the scale 1- No symptom of shriveling, 2- Slight, first perceptible symptom (<30\%), 3- Moderate Symptom (30-50\%) and 4- Severe symptom (50-100\%). Fruit size using digital vernier caliper $(0-150 \mathrm{~mm})$, temperature for both ambient and refrigerated storage using laboratory water thermometer $\left(0-100^{\circ} \mathrm{C}\right)$. For $\mathrm{pH}$, aliquot of each sample fruit was measured for acidity using a portable Hanna $\mathrm{pH}$ meter. Total soluble solids using Atago handheld refractometer $\left(0-80^{\circ}\right.$ brix $)$ and titratable acidity (\% citric acid for hot pepper and $\%$ malic acid for eggplant) by titration using standard $0.1 \quad \mathrm{~N} \quad \mathrm{NaOH}$ and $1 \%$ phenolphthalein indicator through titration method (Rivera et.al, 2015). Shelf life was the number of days for each fruit sample to reach the limit of marketability (VQR 5), due to shriveling, firmness, and/or decay. Water Content (\%) was calculated by subtracting the initial weight to oven dry weight divided by the initial weight times 100 hundred. Dry matter Content (\%) was calculated by dividing the oven-dried weight with the initial weight times one hundred.

\section{Statistical analysis}

Two sets of experiment (hot pepper and eggplant) were conducted in a factorial experiment using completely randomized design, with three replications. Data were subjected to Analysis of Variance (ANOVA). Mean comparison was analyzed using Least Significant Difference at $p \leq 0.05$. All analyses were performed using statistical tool for agricultural research, STAR program ver. 2.0. (2014). Principal component analysis was implemented using XLSTAT statistical software to evaluate the changes on postharvest quality of solanaceous crops treated with pyroligneous acid and stored at ambient and refrigerated condition after 4 days of storage.

\section{Results and Discussion}

Effects of pyroligneous acid and storage conditions on hot pepper

Percent cumulative weight loss on hot pepper revealed no significant effects on varying levels of concentration of pyroligneous acid. However, significant differences were evident on the type of storage. Ambient storage of hot pepper resulted to higher weightloss after 4 days of storage relative to fruit samples kept in refrigerated condition (Fig 2). Similar findings were also noted on degree of shriveling, sample fruits stored in ambient regardless of pyroligneous acid treatment and concentration showed $\quad \operatorname{significantly}(p<0.05) \quad$ higher shriveling indices resulting to shrinkage in fruit size and shorter shelf-life relative to the control (Table 2.) This agreed to the study of Bayogan et al. (2017) wherein they concluded that storage of sweet pepper in the evaporative cooler (EC) storage conditions had significant effect $(p \leq 0.05)$ on the shelf life of the sweet peppers, resulting in reduced weight loss (9.65\% and $28.86 \%$ for 'Sweet Cayenne' and 'Sultan', respectively), slower decline in 
moisture content and longer retention of acceptable visual quality and firmness due to lesser color change and shriveling, respectively. No significant differences were observed on $\mathrm{pH}$, total soluble solid content, titratable acidity, water content and dry matter. These findings agree with Abdullah and Srour (2019) wherein all postharvest treatments retained their weight during storage as compared with untreated control. These might be due to the loss in moisture through transpiration and loss in dry matter content due to respiration during storage. The general rule is that lowering the temperature level decreases the produce respiratory activity. This also minimizes the maturation processes, pathogen action and weight loss occurrence

Highly significant variations $(p<0.01)$ between storage conditions were noted. Firmness of hot pepper stored in refrigerated condition regardless of pyroligneous acid treatment were maintained compared to ambient storage. Marked variations on firmness was manifested on the $3^{\text {rd }}$ day of storage particularly on hot pepper treated with $20 \%$ (v/v) of pyroligneous acid regardless of storage, firmness was significantly lower relative to other treatment combinations (Fig 4). Similarly, hot pepper treated with $30 \% \mathrm{v} / \mathrm{v}$ of pyroligneous acid have better visual quality rating at day 3 of storage regardless of storage condition, but this was insignificant at day 4 as it reaches its limit of marketability (Fig 4). This was also supported by the color change exhibited by some hot pepper samples after 4 days of storage with respect to the mean temperatures during the experiment (Fig 1). During prolonged storage, the main factors for the quality degradation of sweet pepper include poor external appearance, decay development, shriveling associated with water loss and its high susceptibility to chilling injury (Shehata et al. 2013). Reddening of some samples after 4 days were evident but were not statistically reduced by storage at ambient and refrigerated condition though was delayed after three days by higher pyroligneous acid treatment (Fig 3).

Fruit decay of hot pepper regardless of storage conditions were dramatically reduced by treatment of pyroligneous acid at higher concentrations. Hot pepper samples treated with $30 \% \mathrm{v} / \mathrm{v}$ of pyroligneous acid have significantly $(p<0.05)$ minimal fruit decay incidence relative to control. This was also reduced even further with the storage at refrigerated condition (Table 2 ).

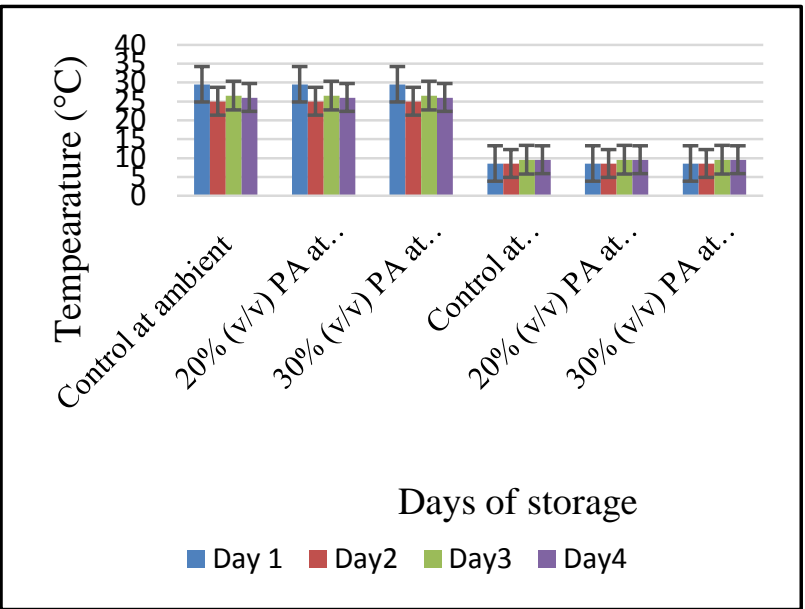

Figure 1. Daily mean temperature $\left({ }^{\circ} \mathrm{C}\right)$ of solanaceous crops treated with different concentrations of pyroligneous acid (PA), B1 - Control (no application), B2 - 20\% (v/v) PA, B3 - 30\% (v/v) PA and stored at A1ambient $\left(25-30^{\circ} \mathrm{C}\right)$ and A2-refrigerated (8$10^{\circ} \mathrm{C}$ ) condition. 


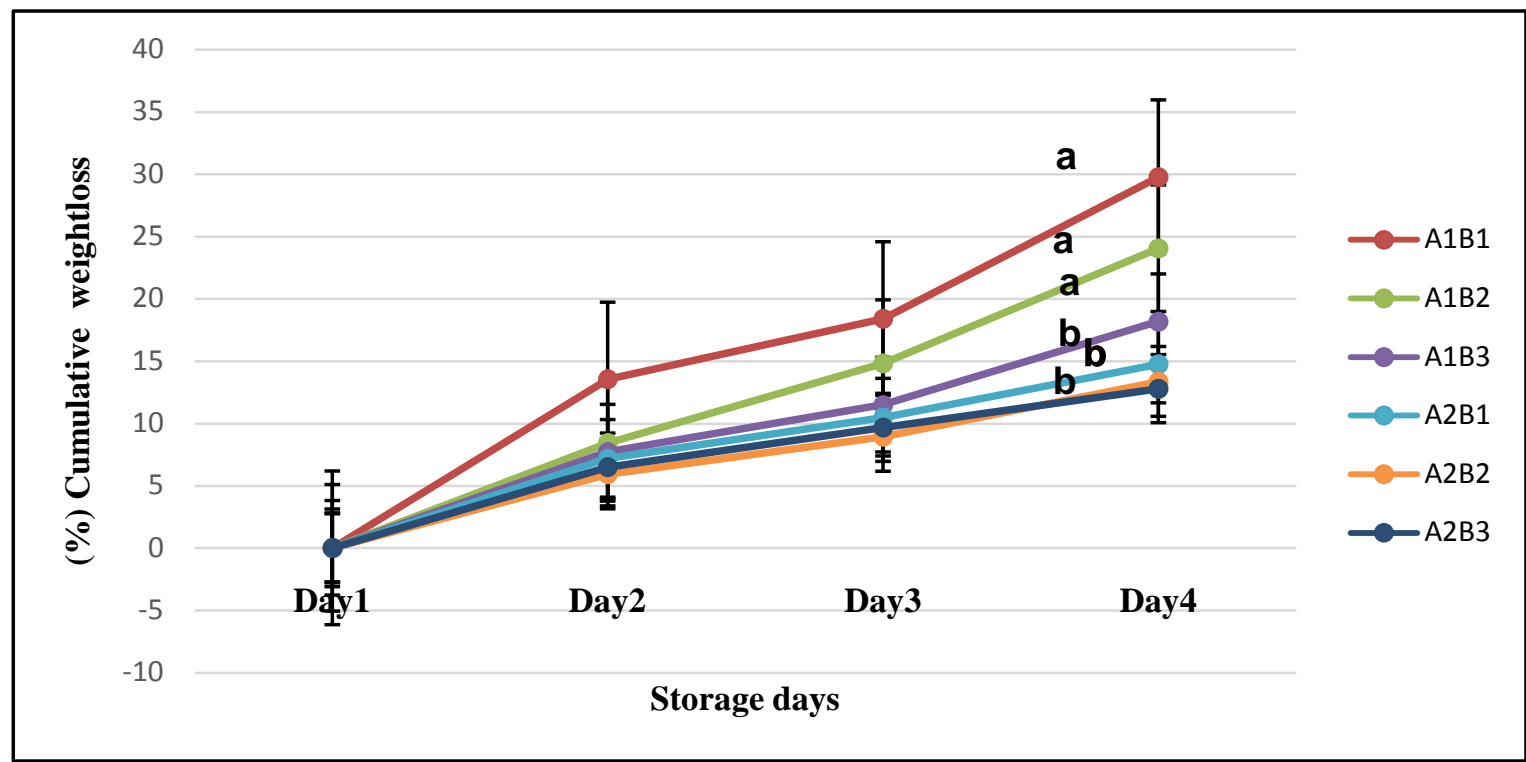

Means with the same letter are not significantly different at LSD $(p<0.05)$

Figure 2. Cumulative weight loss of hot pepper and eggplant treated with different concentrations of pyroligneous acid (PA), B1 - Control (no application), B2 - 20\% (v/v) PA ,B3 $-30 \%(\mathrm{v} / \mathrm{v}) \mathrm{PA}$ and stored at A1- ambient $\left(25-30^{\circ} \mathrm{C}\right)$ and A2-refrigerated $\left(8-10^{\circ} \mathrm{C}\right)$ condition.

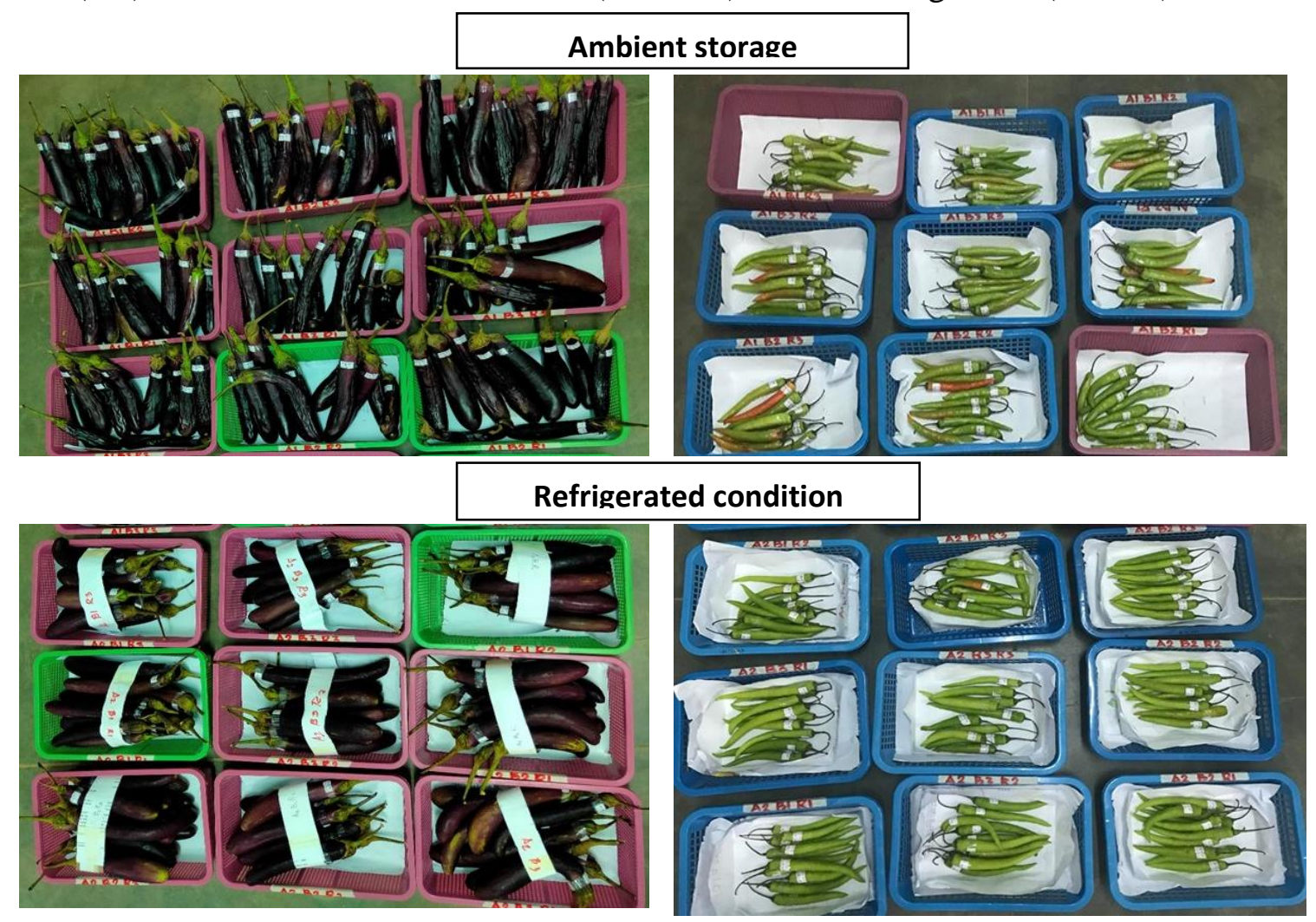

Figure 3. Perspective view of hot pepper and eggplant treated with different concentrations of pyroligneous acid (PA), B1 - Control (no application), B2 - 20\% $(\mathrm{v} / \mathrm{v}) \mathrm{PA}, \mathrm{B} 3-30 \%(\mathrm{v} / \mathrm{v}) \mathrm{PA}$ and stored at A1- ambient $\left(25-30^{\circ} \mathrm{C}\right)$ and A2-refrigerated $\left(8-10^{\circ} \mathrm{C}\right)$ condition. 

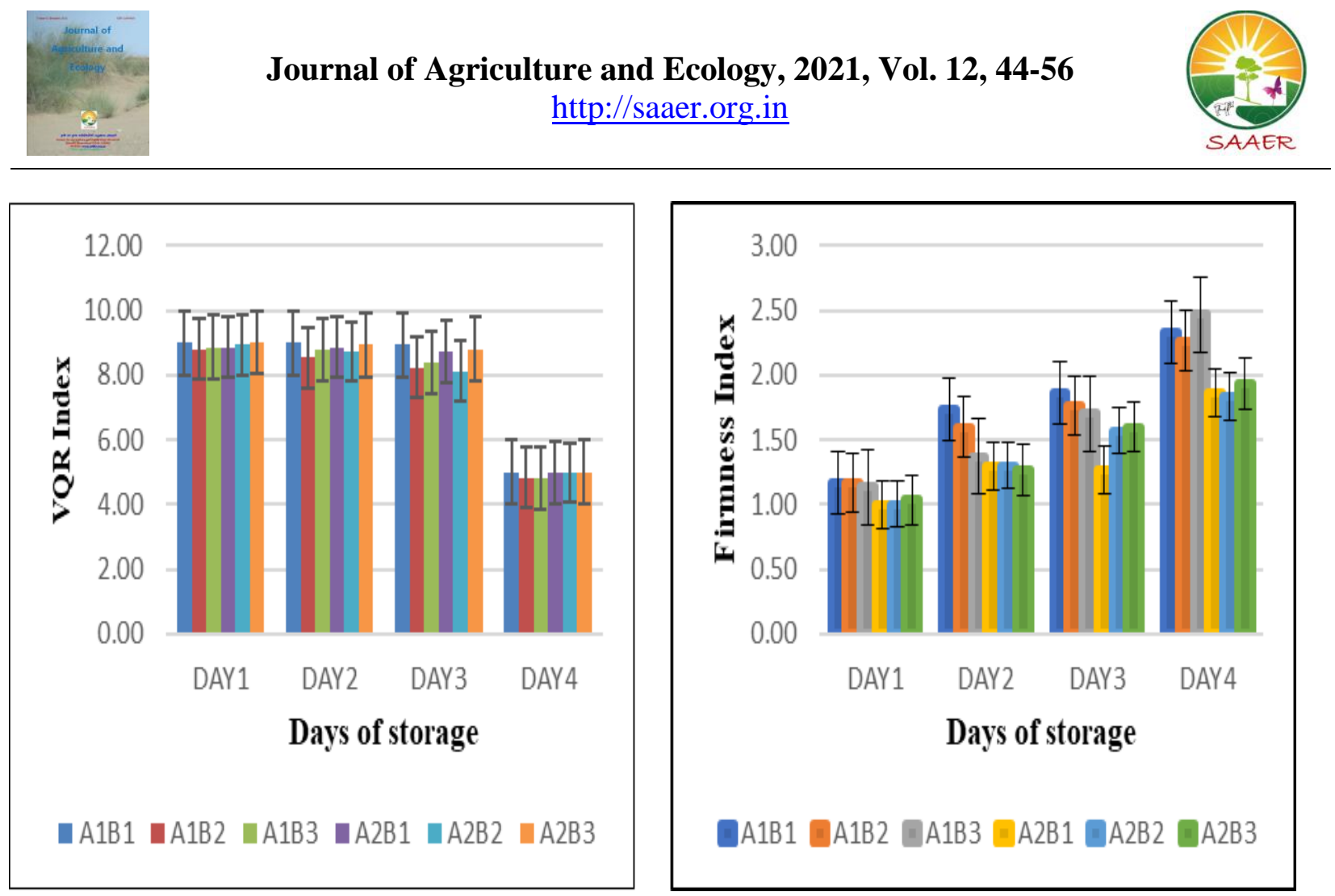

Figure 4. Visual quality rating and firmness of hot pepper treated with pyroligneous acid after 4 days of storage at ambient and refrigerated temperature. Storage conditions at A1- ambient (25$30^{\circ} \mathrm{C}$ ) and A2-refrigerated $\left(8-10^{\circ} \mathrm{C}\right)$. Pyroligneous acid (PA), B1 - Control (no application), B2 $-20 \%(\mathrm{v} / \mathrm{v}) \mathrm{PA}, \mathrm{B} 3-30 \%(\mathrm{v} / \mathrm{v}) \mathrm{PA}$ and stored at A1- ambient $\left(25-30^{\circ} \mathrm{C}\right)$ and $\mathrm{A} 2-$ refrigerated $\left(8-10^{\circ} \mathrm{C}\right)$ condition.

Table 2. Morphological characteristics of hot pepper (Capsicum annuum) treated with pyroligneous acid and stored at different storage conditions (ambient, $25-30^{\circ} \mathrm{C}$ and refrigerated, $\left.8-10^{\circ} \mathrm{C}\right)$.

\begin{tabular}{|c|c|c|c|c|}
\hline $\begin{array}{l}\text { Pyroligneous acid }(\mathrm{PA})+ \\
\text { Storage treatment combinations }\end{array}$ & $\begin{array}{c}\text { Degree } \\
\text { of Shriveling }\end{array}$ & $\begin{array}{c}\text { Fruit } \\
\text { Decay } \\
(\%)\end{array}$ & $\begin{array}{l}\text { Fruit size } \\
\qquad(\mathrm{cm})\end{array}$ & $\begin{array}{l}\text { Shelf-life } \\
\text { (days) }\end{array}$ \\
\hline Control at ambient & $2.84^{\mathrm{a}}$ & $30.00^{b}$ & $28.48^{b}$ & $3.79^{b}$ \\
\hline $20 \%(\mathrm{v} / \mathrm{v}) \mathrm{PA}$ at ambient & $2.84^{\mathrm{a}}$ & $23.33^{\mathrm{a}}$ & $28.48^{b}$ & $3.79^{b}$ \\
\hline $30 \%(\mathrm{v} / \mathrm{v})$ PA at ambient & $2.84^{\mathrm{a}}$ & $10.00^{b}$ & $28.48^{b}$ & $3.79^{b}$ \\
\hline Control at refrigeration & $2.66^{\mathrm{b}}$ & $23.33^{\mathrm{a}}$ & $32.19^{\mathrm{a}}$ & $4.00^{\mathrm{a}}$ \\
\hline $20 \%(\mathrm{v} / \mathrm{v}) \mathrm{PA}$ at refrigeration & $2.66^{\mathrm{b}}$ & $6.67^{\mathrm{ab}}$ & $32.19^{\mathrm{a}}$ & $4.00^{\mathrm{a}}$ \\
\hline $30 \%(\mathrm{v} / \mathrm{v}) \mathrm{PA}$ at refrigeration & $2.66^{\mathrm{b}}$ & $3.33^{b}$ & $32.19^{\mathrm{a}}$ & $4.00^{\mathrm{a}}$ \\
\hline $\mathrm{CV}(\%)$ & 5.21 & 8.52 & 6.54 & 4.49 \\
\hline
\end{tabular}

Means followed by the same letter are not significantly different at $L S D(p<0.05)$ 
Beuchat and Pitt (2001) explained that in fruits, mold growth is generally associated with organoleptic concerns, such as breakdown in fruit texture and the generation of off flavors. Loo et al. (2007) also elucidated the strong antimicrobial activity of pyroligneous acid that was correlated to its high contents of organic acids and phenolic substances.

\section{Effects of pyroligneous acid and storage conditions on eggplant}

There were no significant results on eggplant titratable acidity (TA), dry matter content, water content, percent fruit decay and shelf-life. Eggplant exhibited better visual quality rating at day3 regardless of storage condition. Significant changes $(p<0.05)$ were observed for color, \% cumulative weightloss, $\mathrm{pH}$, total soluble solids. Highly significant $(p<0.01)$ results were showed on fruit size, degree of shriveling and firmness.

Color changes ( $\mathrm{L}^{*}$ values), eggplant stored at refrigerated condition retained darker color relative to fruit samples stored at ambient after 4 days of storage. Increment in percent weightloss was evident at day 2 when stored at ambient but was found insignificant after 4 days of storage.

Degree of shriveling and firmness of eggplant was distinctly higher in ambient storage from day1 to day4, thus shriveling was maintained better when stored under refrigerated condition. $\mathrm{pH}$ also was lower at ambient compared to refrigeration. Nevertheless, Concellon et al (2005) emphasized that storage below $12{ }^{\circ} \mathrm{C}$, eggplants suffer rapid physiological disorders manifested mainly by the appearance of surface injuries such as pitting and browning.
On the other hand, total soluble solids (TSS) regardless of storage condition were significantly higher in control but comparable with the application of $20 \% \mathrm{v} / \mathrm{v}$ of pyroligneous acid. This implies less reduction of soluble solids when treated with $30 \% \mathrm{v} / \mathrm{v}$ of pyroligneous acid, though was comparable with $20 \% \quad \mathrm{v} / \mathrm{v}$ pyroligneous acid.

Table 3. Physico-chemical characteristics of eggplant (Solanum melongena) treated with pyroligneous acid and stored at different storage conditions (ambient, $25-30^{\circ} \mathrm{C}$ and refrigerated, $8-10^{\circ} \mathrm{C}$ ).

\begin{tabular}{lccc}
\hline $\begin{array}{c}\text { Pyroligneous } \\
\text { acid (PA) }+ \\
\begin{array}{c}\text { Storage } \\
\text { treatment } \\
\text { combinations }\end{array}\end{array}$ & $\mathrm{pH}$ & $\begin{array}{c}\text { Total } \\
\text { Soluble } \\
\text { Solids } \\
\left({ }^{\circ} \text { Brix }\right)\end{array}$ & $\begin{array}{c}\text { Titratab } \\
\text { le } \\
\text { Acidity } \\
(\%)\end{array}$ \\
\hline $\begin{array}{l}\text { Control at } \\
\text { ambient }\end{array}$ & $4.96^{\mathrm{b}}$ & $5.70^{\mathrm{b}}$ & 0.17 \\
$\begin{array}{l}20 \%(\mathrm{v} / \mathrm{v}) \mathrm{PA} \\
\text { at ambient }\end{array}$ & $4.96^{\mathrm{b}}$ & $6.00^{\mathrm{ab}}$ & 0.20 \\
$\begin{array}{l}30 \%(\mathrm{v} / \mathrm{v}) \mathrm{PA} \\
\text { at ambient }\end{array}$ & $4.96^{\mathrm{b}}$ & $6.12^{\mathrm{a}}$ & 0.23 \\
$\begin{array}{l}\text { Control at } \\
\text { refrigeration }\end{array}$ & $5.06^{\mathrm{a}}$ & $5.70^{\mathrm{b}}$ & 0.13 \\
$\begin{array}{l}20 \%(\mathrm{v} / \mathrm{v}) \text { PA } \\
\text { at refrigeration }\end{array}$ & $5.06^{\mathrm{a}}$ & $6.00^{\mathrm{ab}}$ & 0.16 \\
$\begin{array}{l}30 \%(\mathrm{v} / \mathrm{v}) \text { PA } \\
\text { at refrigeration }\end{array}$ & $5.06^{\mathrm{a}}$ & $6.12^{\mathrm{a}}$ & 0.23 \\
\hline $\mathrm{CV}(\%)$ & 0.9038 & 4.07 & 30.32
\end{tabular}

Means with the same letter are not significantly different at LSD ( $p<0.05)$

Moradinezhad et al (2018) revealed that total soluble solid increases in all the fruits especially in climacteric fruits as the fruit ripens, there carbohydrates are converted to simple sugars. However, eggplant used in this study is non-climacteric and is chilling sensitive and thus, only small changes of TSS are expected. Serrano et al (2010) stated that organic acid content in stored fruit decreases during ripening and storage because organic acids are used as substrates for respiratory 
metabolism. Basically, application of pyroligneous acid at $30 \%(\mathrm{v} / \mathrm{v})$ retained better total soluble solid content of eggplant irrespective with storage conditions.
Nonetheless, refrigeration delayed color changes, $\%$ cumulative weightloss, $\mathrm{pH}$, fruit size, degree of shriveling and firmness.

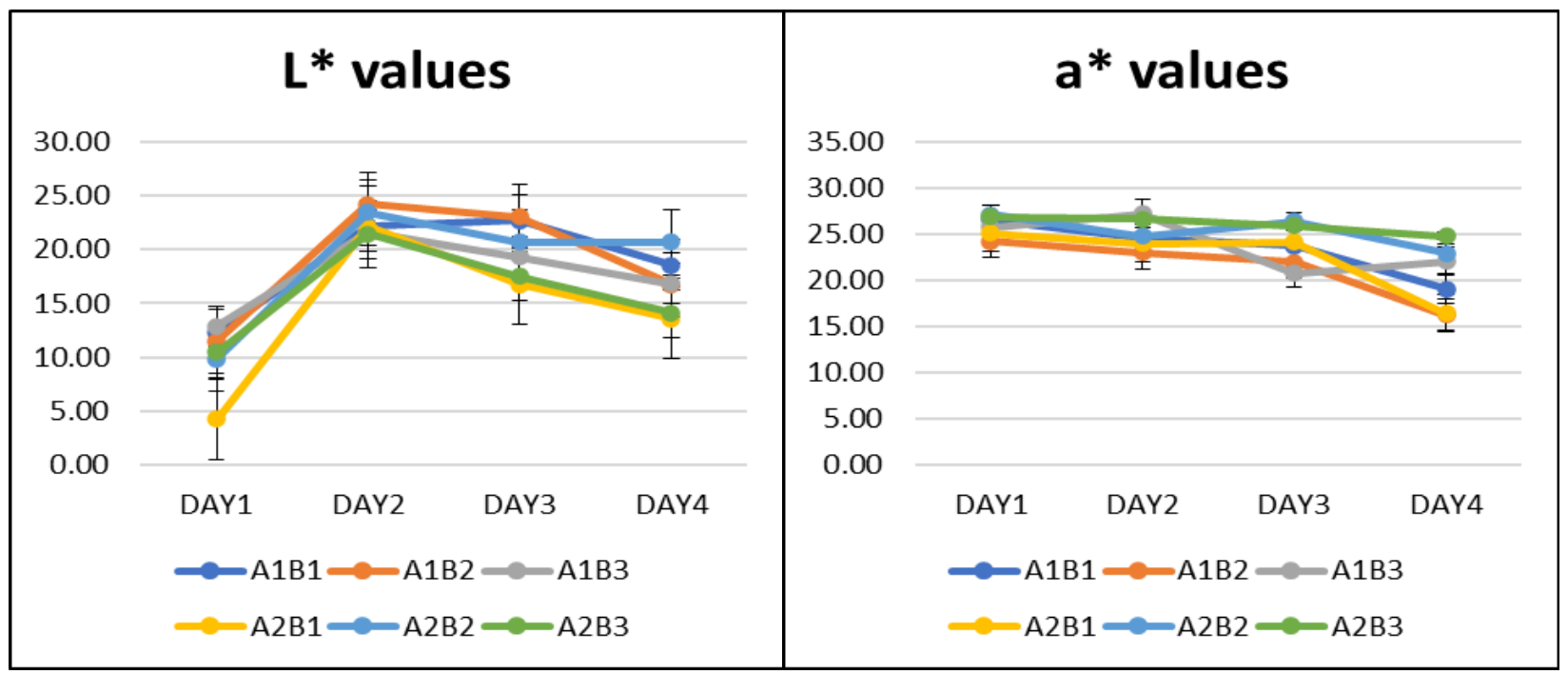

Figure 6. Visual quality rating and firmness of eggplant treated with pyroligneous acid after 4 days of storage at ambient and refrigerated temperature. Storage conditions at A1- ambient (25$30^{\circ} \mathrm{C}$ ) and A2-refrigerated $\left(8-10^{\circ} \mathrm{C}\right)$. Pyroligneous acid (PA) concentration, B1 - Control (no application), B2 - 20\% (v/v) PA, B3 - 30\% (v/v) PA

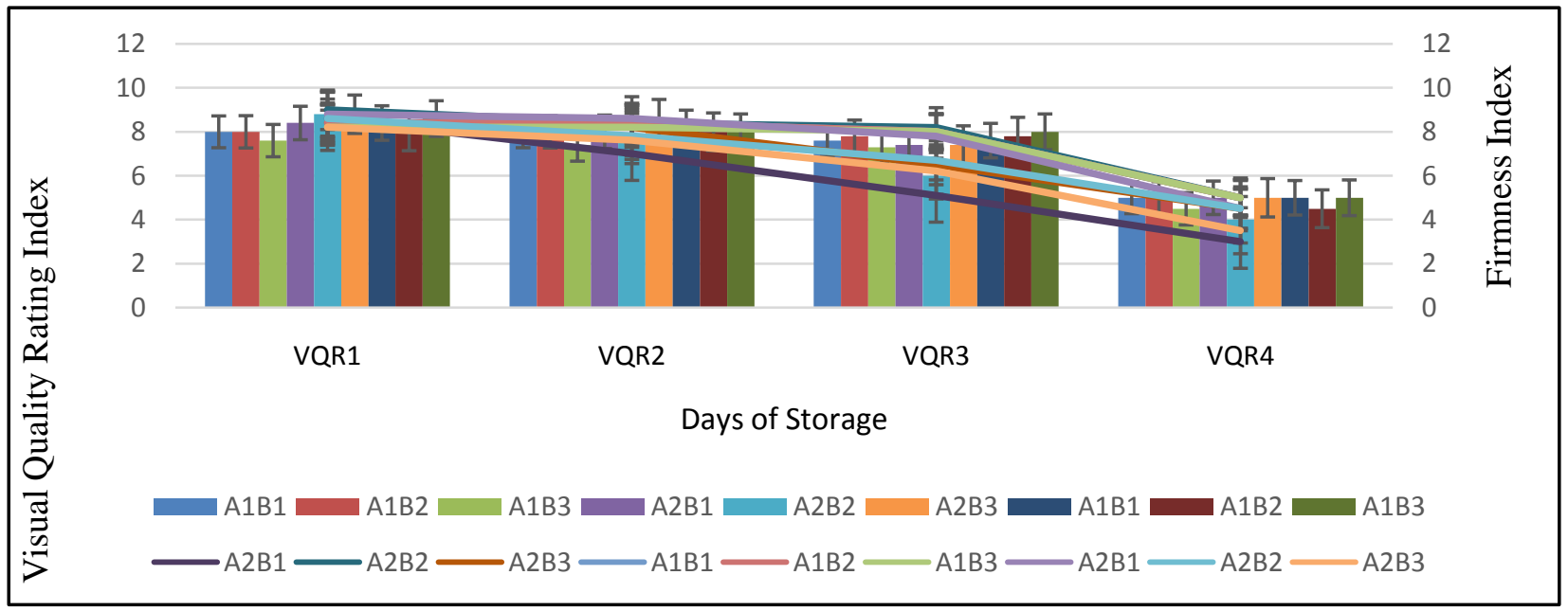

Means with the same letter are not significantly different at $L S D(p<0.05)$.

Figure 7. Color change $\mathrm{L}^{*}$ and $\mathrm{a}^{*}$ values of eggplant treated with pyroligneous acid after 4 days of storage at ambient and refrigerated temperature. Storage conditions at A1- ambient $\left(25-30^{\circ} \mathrm{C}\right)$ and A2-refrigerated $\left(8-10^{\circ} \mathrm{C}\right)$. Pyroligneous acid (PA) concentration, B1 - Control (no application), B2 - 20\% (v/v) PA, B3 - 30\% (v/v) PA 

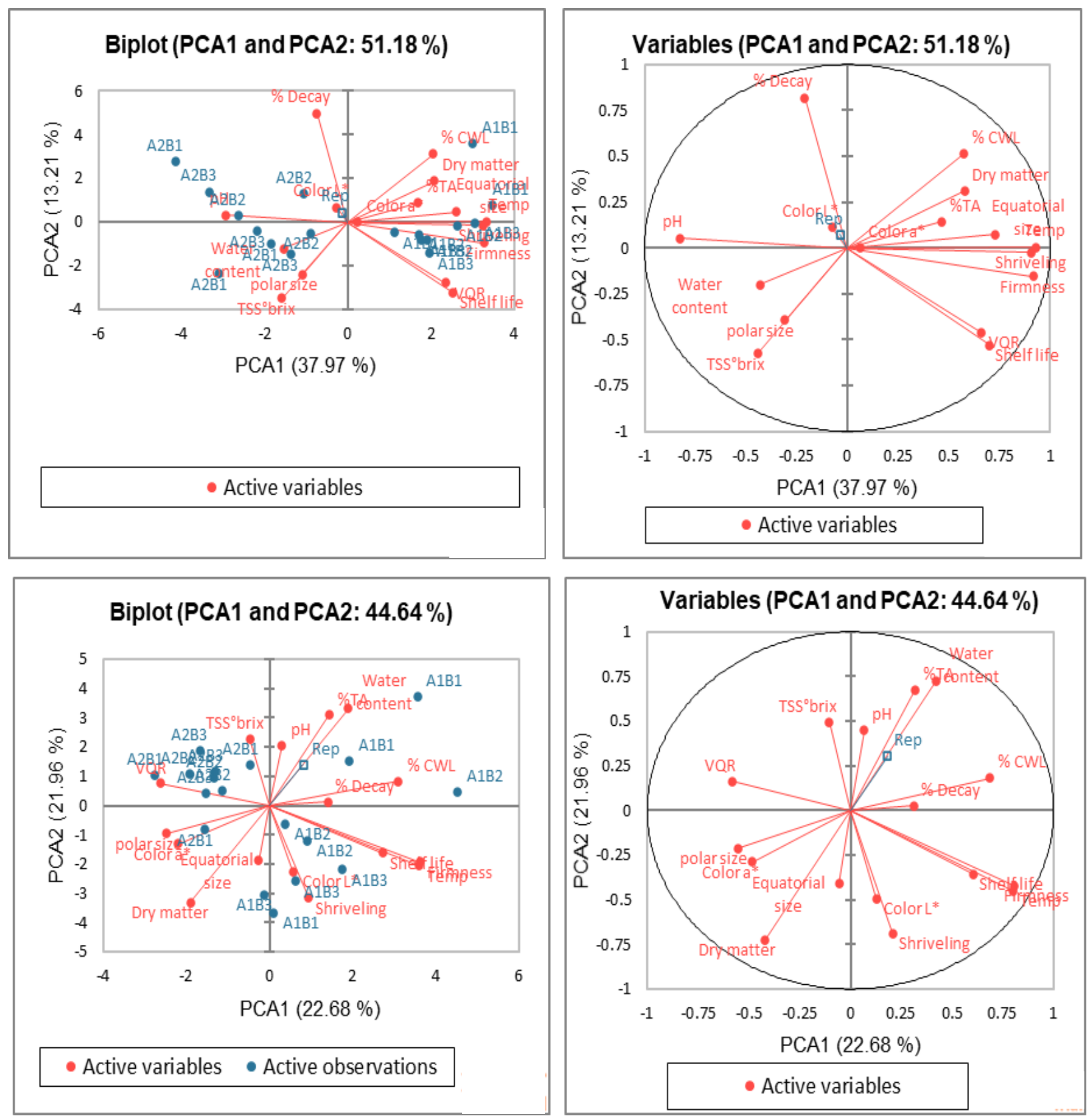

Figure 8. Principal component analysis (PCA) of eggplant (A) and hot pepper(B) treated with pyroligneous acid after 4 days of storage at ambient and refrigerated condition. Storage conditions at $\mathrm{A} 1-$ ambient $\left(25-30^{\circ} \mathrm{C}\right)$ and $\mathrm{A} 2$-refrigerated $\left(8-10^{\circ} \mathrm{C}\right)$. Pyroligneous acid (PA) concentration, B1 - Control (no application), B2 - 20\% (v/v) PA, B3 - 30\% (v/v) PA

\section{Principal Component Analysis}

Principal component analysis (PCA) is known as one of the best techniques owing to its simplicity, interpretation quality, and effectiveness to explaining variations in data set, where was conducted using XLSTAT statistical software. The PCA was implemented on evaluation of postharvest fruit qualities and to statistically classify different 
samples based on a wide range of parameters (Figure 8).

PCA1 and PCA2 describe total variations for eggplant $51.18 \%$ and $44.64 \%$ for hot pepper. Color changes, firmness, fruit size, $\%$ cumulative weightloss (CWL), \% fruit decay, visual quality rating, shelf-life, $\%$ dry mater and $\%$ water content, $\mathrm{pH}$, total soluble solids, and titratable acidity) in hot pepper and eggplant after 4 days of storage were considered as the variables.

In accordance with the PCA plots, several parameters were enhanced in the postharvest treatment of higher pyroligneous acid concentration and different storage conditions on eggplant and hot pepper fruits after 4 days of storage. Figure 8 showed close relationships on eggplants' \% CWL, \%TA, shriveling, fruit size, firmness, VQR and shelf-life. While for hot pepper, VQR, firmness, dry matter, water content shelf-life, $\% \mathrm{TA}, \% \mathrm{CWL}$ and shriveling are positively correlated. Variables within the narrow angles of PCA plot reflect positive-linked and are positively correlated. Consequently, right angles depict variables that are unrelated to each other, while variables found within an obtuse angle represent negative relationship.

\section{References}

Abdullah MA \& Srour HAM. 2019. Enhancement of sweet pepper fruits quality and storability by some postharvest treatments. Annals of Agric. Sci., 57(2) (2019), 447-454.

Bayogan ER, Salvilla R, Majomot AMC \& Acosta J. 2017. Shelf life of two sweet pepper (Capsicum annuum) cultivars

\section{Conclusion}

Fruits of both solanaceous crops reached its limit of marketability at visual quality rating index of three in the $4^{\text {th }}$ day of storage. Morphological characteristics particularly visual quality, firmness, shelf life and degree of shriveling was maintained better when stored under refrigerated condition. Fruit decay incidence regardless of storage condition was reduced especially with higher concentration of pyroligneous acid treatment. However, there were no marked variations of pyroligneous treatment on physico-chemical characteristics, color change, water content and dry matter content. A similar study can be conducted using different levels of pyroligneous acid from different source of material, as well as varying varieties of solanaceous crops. This study could served as an intervention for further studies related to efficacy of pyroligneous acid as postharvest treatment on perishable crops for better marketability.

\section{Acknowledgement}

We would like to thank the Research Committee of the College of Agriculture and Technology, Northwest Samar State University, and the Abuyog Experimental Station for the analysis of the pyroligneous acid that was utilized in this study.

Ahmad MS \& Siddiqui MW. 2016. Postharvest Quality Assurance of Fruits, Springer International Publishing Switzerland pp.7-27. DOI 10.1007/978-3319-21197-8_2.

stored at ambient and evaporative cooling conditions. South Western Journal of 
Horticulture, Biology and Environment, 8 (1): 1-15.

Benitez MM, Saludes B, Rivera FR, Sudaria MAM, Hinayon E, Sudaria E, Salabao A, Ekman J. 2021. Post-harvest characteristics of tomatoes (Solanum lycopersicum L.) as affected by treatment with hot water and sodium hypochlorite under three simple evaporative coolers. Asian Journal of Resource Management and Governance, 1(1): 24-37.

Beauchat LR \& Pitt JI. 2001. Detection and enumeration of heat- resistant molds. In Compendium of Methods for the Microbiological Examination of Foods, 4th edition, F.P. Downes, ed., American Public Health Association, Washington, D.C.

Concellon A, Anon MC \& Chaves AR. 2005. Effect of chilling on ethylene production in eggplant fruit. Food Chemistry, 92: 6369.

Crespo PC \& del Amor FM. 2010. Effects of postharvest treatments on fruit quality of sweet pepper at low temperature. $J$ Sci Food Agric, 90:2716-2722.

Hautea DM, Taylo LD, Masanga APL, Sison MLJ, Narciso JO, Quilloy RB, et al. 2016. Field performance of $\mathrm{Bt}$ eggplants (Solanum melongena L.) in the Philippines: Cry1Ac expression and control of the eggplant fruit and shoot borer (Leucinodes orbonalis Guenee). PLoS ONE, 11(6): e0157498. doi:10.1371/journal.pone.0157498.

Loo AY, Jain K \& Darah I. 2007. Antioxidant and radical scavenging activities of the pyroligneous acid from Mangrove plant
Rhizhopora apiculata. Food Chem., 104:300-307.

Mohan D, Pittman CU \& Steele PH. 2006. Pyrolysis of wood/biomass for bio-oil: acritical review. Energy Fuels, 20: 848889.

Moradinezhad F, Naeimi A \& Farhangfar H. 2018. Influence of edible coatings on postharvest quality of fresh Chinese jujube fruits during refrigerated storage. Journal of horticulture and Postharvest Research, $1(1)$, $1-14$. DOI:10.22077/jhpr.2018.1119.1002.

Oramahi HA \& Yoshimura T. 2013. Antifungal and antitermitic activities of wood vinegar from Vitex pubescens, Vahl. J. Wood Sci., 59(4):344-350.

Seo-Young OH and Seok Chan Koh. 2019. Fruit development and quality of hot pepper (Capsicum annuum L.) under various temperature regimes. Horticultural Science and Technology, 37(3): 313-321.

Serrano M, Valverde JM, Guillen F, Castillo S, Martinez-Romero D \& Valero D. 2006. Use of Aloe vera gel coating preserves the functional properties of table grapes. Journal of Agricultural and Food Chemistry, 54, 3882-3886.

Shehata SA, Ibrahim MIA, El-Mogy MM \& El-Gawad KFA. 2013. Effect of hot water dips and modified atmosphere packaging on extending the shelf life of bell pepper fruits. Wulfenia Journal, 20(3): 315-328.

Tuntika M, Thawan K, Sumran P, Banyong T \& Darunee J. 2013. Wood vinegar and fermented bioextracts: natural products to enhance growth and yield of tomato (Solanum lycopersicum L.). Sci. Hort., 154:66-72. 
Valida A, Benitez M, Rivera FR, Sudaria MA, Salabao A, Sudaria E, Acedo AJ, Winley E \& Ekman J. 2016. Postharvest quality of wood vinegar-treated eggplants under various storage conditions. BANWA ojs.upmin.edu.ph

Wei Q, Ma X \& Dong J. 2010. Preparation, chemical constituents and antimicrobial activity of pyroligneous acids from walnut tree branches. J. Anal. Appl. Pyrol., 87:2428.
Youssef AR, Enas AMA, Hala EE. 2015. Influence of postharvest applications of some edible coating on storage life and quality attributes of navel orange fruit during cold storage. Int. J. ChemTech Res., 8(4): 2189-2200.

Zhang M \& Ok YS. 2014. Biochar soil amendment for sustainable agriculture with carbon and contaminant sequestration. Carbon Management, 5, 255-257. 